\title{
The Effect of Instructing Impression Management Behaviors on Maximizing Applicants' Performance in the IELTS Speaking Test
}

\author{
Sara Namdar (Corresponding author) \\ Islamic Azad University, Bandar Abbas Branch, Bandar Abbas, Iran \\ E-mail: sara_namdar26@yahoo.com.
}

Mohammad Sadegh Bagheri

Dept. of foreign languages, Shiraz branch, Islamic Azad University, Shiraz, Iran

E-mail: bagheries@gmail.com

Received: December 28, 2011

Accepted: January 17, 2012

Published: April 1, 2012

doi:10.5539/elt.v5n4p150

URL: http://dx.doi.org/10.5539/elt.v5n4p150

\begin{abstract}
Speaking proceeds under the constraint of time. While speaking, speakers are under constant pressure to follow the message being received and to formulate rapid responses to their partners. In the IELTS (International English Language Testing System) Speaking Test, the communicative nature of the interview creates an ideal situation for applicants to use impression management (IM) behaviors. Sixty IELTS students studying in Bahar institute of Shiraz, Iran were selected for this study and assigned to two groups of control and experimental. The experimental group received treatment and students were taught IM tactics. At the end of the course, students took part in the test and their oral proficiency was measured by a certified IELTS examiner. The interviews were also videotaped and the participants were asked to attend a post-test interview and to fill out a post-test questionnaire, too. The results proved the positive effect of IM instruction on candidates' performance in the IELTS Speaking test.
\end{abstract}

Keywords: Impression Management behaviors, IELTS Speaking Test, Performance

\section{Introduction}

IELTS, the International English Language Testing System, is a test of English language proficiency which is now jointly administered by the University of Cambridge Local Examinations Syndicate (UCLES), the British Council, and the IDP Education Australia. It is designed to assess the language ability of candidates who intend to study, work, or live where English is used as the language of communication.

IELTS tests all four language skills - Listening, Reading, Writing and Speaking.

The Speaking test is a face-to-face interview with a certified Examiner. It lasts between 11 and 14 minutes and comprises three phases. In Phase 1, which lasts 4-5 minutes; the candidates answer general questions about themselves, their home/family, their jobs/studies, their interests, and a range of similar familiar topic areas. In Phase 2 (3-4 minutes) the candidates speak for one to two minutes on a particular topic. The topic is written on a card, and the candidate has one minute to prepare for the talk. $\mathrm{S} / \mathrm{he}$ is asked one or two follow-up questions. In Phase 3 (4-5 minutes) the examiner and candidate discuss issues and concepts thematically linked to Phase 2 . It is about more abstract ideas and the candidate has to express and justify an opinion. The interview is recorded on audio cassettes. Maximum speaking proficiency is then rated against the Band Scale.

In the oral proficiency interviews such as the IELTS interview, careful preparation along with good interview techniques provide candidates with all the tools they need to achieve desirable results. Different categories of skills/strategies are presented with the aim of supporting candidates' success in the IELTS speaking test. However as the focus of this study is on the effect of Impression Management tactics, we just center on these strategies and the consequential effects of them on candidates' performance.

Impression Management is the process by which people attempt to influence the images others have of them during social interaction, either consciously or unconsciously (Fletcher, 1989, 1990; Schneider, 1981). Scholars have adapted impression management theory from social psychology and applied it to a variety of settings such as: organizational settings, educational settings, job interviews, politics, etc. Interviews are important settings for impression management. What applicants say and do in an interview affect their performance and consequently the 
interviewers' evaluations of them. Both lab and field studies have typically demonstrated a positive relationship between applicant impression management and interviewer evaluations (e.g., Higgings \& Judge 2004; Peters \& Lievens 2006; Tsai, Chen, \& Chiu 2005).

According to Schneider (1981), IM can take many forms, including verbal and nonverbal IM tactics. Among the tactics used in different interview settings, the nonverbal are almost the same. First impressions are formed mostly by nonverbal communications including appearance, facial expressions, eye contact, posture, and, least of all, spoken words. This study, however, focuses on the use and effectiveness of the following nonverbal impression management tactics:

- Smiling at the target

- Making eye contact

- Using hand gestures

- Nodding affirmatively

Verbal IM tactics, on the other hand, are different based on the type of interview. In fact, different interview formats result in different verbal IM tactic use of candidates. The assessors of proficiency look at what speakers can do with the language and their level of control over the language, not necessarily what they know about the language. For this to happen, teachers should search for the best ways to provide students with tools to communicate, such as through the development of strategic competence. They can develop students' strategic competence by providing learning opportunities to improve their communication strategies (CS). CS refers to those strategies that may be called into action to compensate for breakdowns in communication due to performance variables or to insufficient competence (Canale \& Swain 1980: 30).

The following communication strategies are the tactics that are considered to be conducive to verbal impression management in the OPIs such as the IELTS Speaking Test:

- Circumlocution

- Appeal for assistance

- $\quad$ Time-stalling devices

Circumlocution, a component of strategic competence, is a very important strategy for second/foreign language learners when expressing themselves but lacking the exact vocabulary, especially when they are in the target culture.

Appeal for assistance, is a common communication strategy that seems to be treated as merely a list of phrases for receptive global appeals. The 'basic phrases' are: "I have no idea what you're talking about. How do you say that in English? I don't get it. What do you mean? Can you say that again?"

Finally, Time-stalling devices refer to those strategies which help speakers hold the floor and have time to think. A variety of hesitation devices exist that can help speakers hold the floor and keep the conversation going. These helpful devices can be: "Hmm...Let me think. Hmm... Let me see. That's a difficult question".

\subsection{Research Hypotheses}

As instructions to convey a favorable impression should serve as an impression motivator (Leary \& Kowalski, 1990), we hypothesize:

1.1.1 Applicants will use more verbal IM tactics when they are instructed to convey a favorable impression than when they are not instructed to present themselves favorably.

1.1.2 Applicants will use more nonverbal IM tactics when they are instructed to convey a favorable impression than when they are not instructed to present themselves favorably.

1.1.3 Applicants' use of verbal and nonverbal IM tactics will be positively related to their overall interview evaluations.

\section{Review of Related Literature}

Researchers have suggested that interviews offer individuals the perfect opportunity to manage their impressions because both the interviewer and the applicant are attempting to fit the needs of the other (Godfrey et al 1986). A number of empirical studies support this assertion, showing that IM tactics do, in fact, emerge quite frequently during employment interview situations (e.g., Fletcher 1990; Stevens \& Kristof 1995).

The use of IM in employment interviews has been increasingly studied (e.g., Higgins \& Judge 2004; Kristof-Brown, Barrick, \& Franke 2002). In fact, in their review, Posthuma, Morgeson, and Campion (2002) noted that IM was one of 
the most emergent research topics in interview studies in the last 10 years.

The popular literature on employment interviews abounds with books for applicants on how to do well in an interview with some recent titles including: "Winning Job Interviews" (Powers 2004) and "Sell Yourself: Master the Job Interview Process" (Williams 2004). As these books suggest, instructing or coaching candidates on how to present their positive attributes may help them better convey the skills and abilities they possess. In fact, interview training appears to be related to self-promotion (Kristof-Brown et al 2002). With a better knowledge of the applicant's positive qualities, interviewers might be able to make more valid interview decisions. Higgins and Judge (2004) suggest that future research examine the extent to which impression management is and can be learned.

Much of the existing research on interview training has been conducted with specific populations (e.g., underemployed, unemployed, and patients with psychiatric disorders). Few studies have examined the effects of interviewee training or coaching on job applicants to whom many popular books on interviewing are addressed.

In the last few years, Maurer and colleagues (see Maurer \& Solaman 2006 for a review) conducted studies on interview coaching, which based on their definition, appears to be interchangeable with what is typically labeled, "interview training". Generally, a positive relationship between attending an interview coaching session and interview performance has been shown. They also found that the reliability and validity were somewhat higher in a sample that received coaching compared to an uncoached group. The complete coaching booklet can be found in Maurer \& Solaman (2006).

Helga Peeters \& Filip Lievens (2006) did a study on how structured interview format and Impression Management instruction influenced the use and effectiveness of verbal and nonverbal impression management (IM) in job interview settings. Results from 190 people who were screened for a training program demonstrated that interview format affected the kind of tactics used, which in turn positively influenced interviewers' evaluations. The first interesting finding was that IM instructions influenced the use of verbal IM tactics. More specifically, people who were instructed to convey a favorable impression used more proactive, assertive, self-focused and other-focused verbal tactics than people who were instructed to convey an accurate impression. Their results that IM instructions had no influence on the use of nonverbal tactics suggest that nonverbal behavior might be less intentionally controllable in selection interviews.

Social scientists, on the other hand, have explored the power of nonverbal communication and its impact within a variety of different settings. Studies have shown that effective nonverbal communication, although perhaps more innate to some, can actually be taught and improved through training.

One of the early studies performed on this topic suggested that interviewers tend to evaluate interviewees in areas such as social skill based on their nonverbal behavior (Gifford et al 1985). In addition, nonverbal cues are often used in instances where "information about a person is valuable" and/or "there are reasons to believe that such information can't or won't be explicitly expressed verbally or otherwise". Social settings such as these would include first dates, a court trial, or the employment interview. Due to the fact that interviewers utilize nonverbal cues in assessing applicants, interviewees should focus on utilizing nonverbal communication cues to enhance their impression management skills.

Much of the existing research on Impression Management is in the area of employment interviews and no one has directly examined the relationship between IM use and IELTS Speaking Test evaluations. It seems that the only study done on the effectiveness of IM in the Oral Proficiency Interviews is the one conducted by Luk (2010). He investigated the effect of IM use on the performance of forty-three female Hong Kong secondary students in L2 oral proficiency interview conducted in the form of peer group interactions. Luk focused on how students structured their talk in such a way that they seemed to be consciously employing or unconsciously displaying a variety of discourse strategies for impression management in peer group interaction. The results indicated that students' predominant concern about staging a performance to present the best possible impression of themselves was positively related to their test evaluations.

Luk's study is conducted in the form of peer group interaction. IELTS Speaking Test, however, is a face-to-face interview which conducts in a form of two-way interaction. The tactics considered as having contributed to the creation of positive impressions are different in each of these OPIs accordingly. Therefore, this study aims to focus on the effectiveness of IM instruction on candidates' performance in the IELTS Speaking Test and consequently on interviewer's evaluations.

\section{Method}

\subsection{Participants}

The participants who took part in this study were 60 IELTS students who were taking part in preparation classes of IELTS speaking test in Bahar institute of Shiraz, Iran. Students were chosen from both male and female sex (18 
male \& 42 female) with the age range of 20-30 and almost the same educational backgrounds (BA). They were also homogeneous in terms of their language proficiency in that they had all passed the IELTS Mock exam with the mean score of $5 / 5$ to 6 .

\subsection{Instruments}

In this study, three instruments were used with the purpose of collecting quantitative data: The IELTS Mock exam, the IELTS Speaking Test and a post-test questionnaire. Qualitative data, on the other hand, were obtained through a post-test interview.

\subsubsection{The IELTS Mock Exam}

The first instrument used in the current study was the IELTS Mock exam. This test which was used as a pre-test aimed to measure students' level of proficiency before they take part in preparation classes of the IELTS. Based on the results, students who had passed the exam with the mean score of $5 / 5$ to 6 were put in groups of the same proficiency.

\subsubsection{The IELTS Speaking Test}

The second instrument used in this study was the IELTS Speaking Test. This test which was used as the post-test comprised three phases and it was developed to measure students' speaking proficiency.

\subsubsection{Post-test Questionnaire}

The post-test questionnaire was used as the third instrument to gather quantitative data with respect to the IM tactics students used during the interview. The questionnaire was designed by the researcher and consisted of ten statements on each of the IM tactics to be measured: verbal and nonverbal tactics. The participants responded on the basis of a five point Likert-scale, ranging from strongly agree to strongly disagree. In order to check the validity of the questionnaire, the researcher consulted two members of the thesis committee to analyze it for the validity. After assuring the validity, the questionnaire was administered to students and the data were put into SPSS. Based on the students' responses to the questionnaire, the reliability coefficient, Cronbach's alpha, was found to be 0.79 .

\subsubsection{Post-test Interview}

The qualitative data were collected through a post-test interview. It was a semi-structured interview which aimed to find the strategies students actually used during the Speaking test. The interviews were conducted individually by the researcher with the main purpose of eliciting students' attitudes toward the IM tactics and the evaluation of their own performance. The interviews were tape recorded and were then analyzed by the researcher. The focus of the analysis was on whether IM tactics were helpful in conveying candidates' message more effectively and also the extent to which each group of the tactics were useful.

\subsection{Procedure}

Two groups of students who were taking part in preparation classes of the IELTS Speaking Test in Bahar Institute were chosen for this study, one as the control and the other as the experimental group. Then, a proficiency test (Mock exam) was given to both groups in order to meet homogeneity. This test functioned as a pre-test and was used before applying the proposed strategy. After the pre-test, instruction started and students' speaking skills developed through standard approaches of the IELTS. The experimental group, however, received treatment and students were taught Impression Management tactics too. At the end of the course, students took part in the speaking test and their oral proficiency was measured by an IELTS examiner. The Speaking test was a face-to-face interview which aimed at evaluating the effectiveness of the proposed strategy by comparing the results of the two groups. It was also recorded on a videotape for more analysis. Afterwards, the participants attended a post-test interview and were asked to fill out a post-test questionnaire, too. Through analyzing students' performance recorded on the videotape and their responses in the post-test interview and on the post-test questionnaire, the coders measured the effectiveness of IM instruction on candidates' performance in the test.

\section{Results and Findings}

The scores obtained from the pre-test and the post-test were analyzed through SPSS. The means, standard deviations and the differences of means were computed for each group. Significance of difference between the mean scores of both groups was tested at 0.05 level by applying independent samples $t$-test. Another independent samples $t$-test was also conducted in order to find whether there was any significant difference between males and females' performance in the post-test of the experimental group.

The results of the descriptive statistics conducted to compare the mean scores of the control group in the pre-test and the post-test, indicated a little difference in the two tests which is not important (See Table 1). 
To find whether there was a significant difference between the pre-test and the post-test in the control group, an independent samples t-test was conducted. The results showed that there was not statistically a significant difference between the two tests in the control group at $\mathrm{p}<.05$ significant value (See Table 2).

The results of the descriptive statistics conducted to compare the mean scores of the experimental group in the pre-test and the post-test showed that the minimum average referred to the pre-test (See Table 3).

To find whether there was a significant difference between the pre-test and the post-test in the experimental group, an independent samples t-test was conducted. The results revealed that there was statistically a significant difference between the pre and post tests at $p<.05$ significant value (See Table 4 ).

To find whether there was any significant difference between males and females' performance in the post-test of the experimental group, an independent samples t-test was conducted. The results showed that there was no significant difference between the two genders in the post-test at $\mathrm{p}<.05$ significant value (See Table $5 \& 6$ ).

Through analysis of the post-test questionnaire data, the mean scores of all the questionnaire items were calculated. The results showed students' agreement over all the study variables (IM tactics) (See Table 7).

To find the degree of differences in students' responses to the questionnaire items, a chi-square test was conducted. The results showed that there was statistically no significant difference between students' responses in items 2, 3, 8, 10 as the significant values of these questions were far above the significant value $p<0.05$. In other items; however, two responses were at least different (See Table 8).

Concerning gender differences in the IM preferences of the participants, another chi-square test was conducted and at $\mathrm{p}<.05$ no significant difference was found between the two genders (See Table 9).

Through the analysis of the videotape data, applicants' absolute IM frequencies were calculated. The means and standard deviations of each of the IM tactics were also computed. The results of the descriptive statistics indicated that the most preferred strategy category of all, was the category of time-stalling devices with a mean score of 0.75 . The nonverbal strategy of eye contact ranked the second with an average of 0.66 . The third place in the ranking order was taken by the circumlocution strategy with a mean score of 0.40 . Hand gesture strategy ranked in the fourth place with an average of 0.35 and the nonverbal strategies of smiling and appeal for assistance ranked the fifth and the sixth with the mean scores of 0.19 and 0.16 . Finally, head nodding with a mean score of 0.14 , ranked the least preferred strategy (See Tables 10 \& 11).

To find whether there was any significant difference in the IM preferences of male and female candidates, an independent samples t-test was conducted. Unlike the questionnaire data in which there was not any significant difference in students' attitudes toward IM tactic use, the results of the videotape data showed that there was statistically a significant difference between the two genders in the use of the nonverbal strategy of smiling. In other strategies; however, no significant difference was found between males and females for the significant values of these strategies were far above the significant value $\mathrm{p}<.05$ (See Tables $12 \& 13$ ).

In order to determine whether there was statistically a meaningful relationship between verbal and nonverbal IM tactics, the Pearson correlation was computed. The results revealed that time-stalling strategies significantly correlated with circumlocution and appeal for assistance tactics at $\mathrm{p}<.05$ significant value, the correlation coefficient was found $.461(\mathrm{p}=.010)$ and $-.564(\mathrm{p}=.001)$ respectively. This implies that those who successfully use time-stalling strategies are also good at using circumlocution strategy. The negative correlation between time-stalling and appeal for assistance strategies; however, shows that the increase in using one strategy decreases the use of the other tactic.

The circumlocution strategy, on the other hand, significantly correlated with appeal for assistance, hand gesture and head nodding strategies at $\mathrm{p}<.05$ significant value, the correlation coefficient was found -.693 $(\mathrm{p}=.000), .560$ $(\mathrm{p}=.001)$ and $-.478(\mathrm{p}=.007)$ respectively. This implies that those who are capable of using circumlocution strategy are also good at using hand gesture as a nonverbal strategy. The negative correlation between circumlocution and the strategies of head nodding and appeal for assistance; however, implies a reverse correlation. That is, the increase in using one strategy decreases the use of the other tactic.

It was found that there was a significant relationship between appeal for assistance and head nodding strategies at $\mathrm{p}$ $<.05$ significant level, the correlation coefficient $\mathrm{r}$ was found $.496(\mathrm{p}=.005)$. There was also a significant relationship between the two nonverbal strategies of eye contact and head nodding at $\mathrm{p}<.05$ significant level, the correlation coefficient was found $.416(\mathrm{p}=.022)$.

The results also indicated that none of the IM tactics had statistically a significant relationship with the nonverbal strategy of smiling. This means that the students who participated in this study had difficulty in using smiling 
strategy together with the other tactics (See Table 14).

To find whether there was statistically a meaningful relationship between applicants' IM use and the scores obtained from the post-test, the Pearson correlation was computed. The results revealed that there was statistically a significant relationship between the mean score of each of the IM tactics and that of the post-test results except for the nonverbal tactic of eye contact. As shown in Table 15, the verbal tactics of time-stalling $(r=.001, p<.05)$ and circumlocution $(\mathrm{r}=.000, \mathrm{p}<.05)$ correlated positively with the post-test mean score. There was a positive correlation between the nonverbal strategies of hand gesture $(r=.019, \mathrm{p}<.05)$ and smiling $(r=.015, \mathrm{p}<.05)$ and the post-test mean score too.

It was found that there was a negative correlation between appeal for assistance and head nodding strategies and the post-test mean score, the correlation coefficient was found $-.423(\mathrm{p}=.020)$ and $-.600(\mathrm{p}=.000)$ respectively. This negative correlation means that the use of appeal for assistance and head nodding strategies had no effect on candidates' performance in the post-test.

Finally, the correlation coefficient of $.046(\mathrm{p}=.809)$ showed that there was not statistically any significant relationship between the nonverbal strategy of eye contact and the post-test mean score. This implies that even if there was an effect of eye contact on the post-test scores, this effectiveness was not so significant.

The results obtained from the post-test interview, on the other hand, showed students' positive attitudes toward the IM tactics. Almost all the students referred to IM tactics as effective strategies which helped them overcome their negative emotions, compensate for the gaps in their communication and maximize their performance in the interview. Although some students (about one third of candidates) referred to stress as a barrier to their performance, the rest were all agreed with the effective use of verbal and nonverbal IM tactics and believed that these strategies could be used as effective tools to convey positive impressions to the interviewer and their evaluations of them.

\section{Conclusion}

This study reports a series of experiments regarding the effect of instructing Impression Management tactics on candidates' performance in the IELTS Speaking Test. The findings of the study are encouraging regarding the effect of IM instruction on candidates' performance in the IELTS interview. Therefore, we can conclude that providing IELTS candidates with verbal and nonverbal IM tactics can help them perform better in the interview and maximize their performance in the IELTS Speaking test.

\subsection{Applications and Implications}

This study confirms the effectiveness of teaching Impression Management tactics on candidates' performance in the IELTS Speaking test; so, the findings will be of great value to all the OPI settings in which the purpose of the interview is to assess applicants' speaking skill, what they can do with the language and their level of control over the language.

Oral proficiency tests are currently being used worldwide by academic institutions, government agencies, and private corporations for purposes such as: academic placement, student assessment, program evaluation, professional certification, hiring, and promotional qualification. Teacher certification boards in some states also require evidence of spoken language competency; therefore, IM instruction can be used as a new and interesting method of preparing candidates for such purposes.

\section{References}

Canale, M., \& Swain, M. (1980). Theoretical bases of communicative approaches to second language teaching and testing. Applied Linguistics, 1, 1-47. http://dx.doi.org/10.1093/applin/1.1.1

Fletcher, C. (1989). Impression management in the selection interview. In R. A. Giacalone \& P. Rosenfeld (Eds.), Impression management in the organization (pp. 269-281). Hillsdale, NJ: Lawrence Erlbaum Associates, Publishers.

Fletcher, C. (1990). The relationships between candidate personality, self-presentation strategies, and interviewer assessment in selection interviews: An empirical study. Human Relations, 43, 739-749. http://dx.doi.org/10.1177/001872679004300803

Gifford, R., Ng, C. F., \& Wilkinson, M. (1985). Nonverbal cues in the employment interview: Links between applicant qualities and interviewer judgments. Journal of Applied Psychology, 70, 729-736. http://dx.doi.org/10.1037/0021-9010.70.4.729

Godfrey, D. K., Jones, E. E., \& Lord, C. G. (1986). Self-promotion is not research reports 1207 ingratiating. Journal of Personality and Social Psychology, 50, 106-115. http://dx.doi.org/10.1037/0022-3514.50.1.106

Higgins, C. A., \& Judge, T. A. (2004). The effect of applicant influence tactics on recruiter perceptions of fit and 
hiring recommendations: A field study. Journal of Applied Psychology, 89, 622-632. http://dx.doi.org/10.1037/0021-9010.89.4.622

Kristof-Brown, A., Barrick, M. R., \& Franke, M. (2002). Applicant impression management: Dispositional influences and consequences for recruiter perceptions of fit and similarity. Journal of Management, 28, 27-46. http://dx.doi.org/10.1177/014920630202800103

Leary, M. R., \& Kowalski, R. M. (1990) Impression management: A literature review and two-component model. Psychological Bulletin, 107, 34-47. http://dx.doi.org/10.1037/0033-2909.107.1.34

Luk, J. (2010). Talking to score: Impression management in L2 oral assessment and the co-construction of a test discourse genre. Language Assessment Quarterly, 7, 25-53.

Peeters, H., \& Lievens, F. (2006). Verbal and nonverbal impression management tactics in behavior description and situational interviews. International Journal of Selection and Assessment, 14, 206-222. http://dx.doi.org/10.1111/j.1468-2389.2006.00348.x

Powers, P. (2004). Winning job interviews. New Jersey: Career Press.

Schneider, D. J. (1981). Tactical self-presentations: Toward a broader conception. In J. T. Tedeschi (Ed.), Impression management theory and social psychological research (pp. 23-40). New York: Academic Press.

Stevens, C. K., \& Kristof, A. L. (1995). Making the right impression: A field study of applicant impression management during job interviews. Journal of Applied Psychology, 80, 587-606. http://dx.doi.org/10.1037/0021-9010.80.5.587

Tsai, W. C., Chen, C. C., \& Chiu, S. F. (2005). Exploring boundaries of the effects of applicant impression management tactics in job interviews. Journal of Management, 31, 108-125. http://dx.doi.org/10.1177/0149206304271384

Williams, J. (2004). Sell yourself: Master the job interview process. Arlington, TX: Principle Publications.

\section{Authors}

Sara Namdar: Islamic Azad University, Bandar Abbas Branch, Bandar Abbas, Iran. email: sara_namdar26@yahoo.com. She holds an M.A. from Islamic Azad University, Bandar Abbas Branch and she is currently teaching English at some language institutes. Her area of research is speaking skill and she has delivered some presentations on this issue.

Mohammad Sadegh Bagheri: Dept. of foreign languages, Shiraz branch, Islamic Azad University, Shiraz, Iran. email: bagheries@gmail.com. He earned his M.A. and Ph.D. degrees in TEFL from Shiraz State University, Iran, and is currently an assistant professor teaching at Islamic Azad university, Shiraz Branch. He has a number of publications on TOEFL and IELTS, and has presented some articles at international conferences. Moreover, he is a Cambridge ESOL and IELTS examiner, and runs his own internationally accredited language school which is affiliated with Cambridge University as a sub-center.

Table 1. Descriptive statistics of the control group in the pre-test and the post-test

\begin{tabular}{|l|l|c|c|c|c|}
\hline \multicolumn{2}{|c|}{} & Mean & N & Std. Deviation & Std. Error Mean \\
\hline \multirow{2}{*}{ Pair 1 } & Pretest & 5.7500 & 30 & .28618 & .05225 \\
\cline { 2 - 6 } & Posttest & 5.7750 & 30 & .27347 & .04993 \\
\hline
\end{tabular}

Table 2. Independent samples t-test for the pre-test and post-test differences in the control group

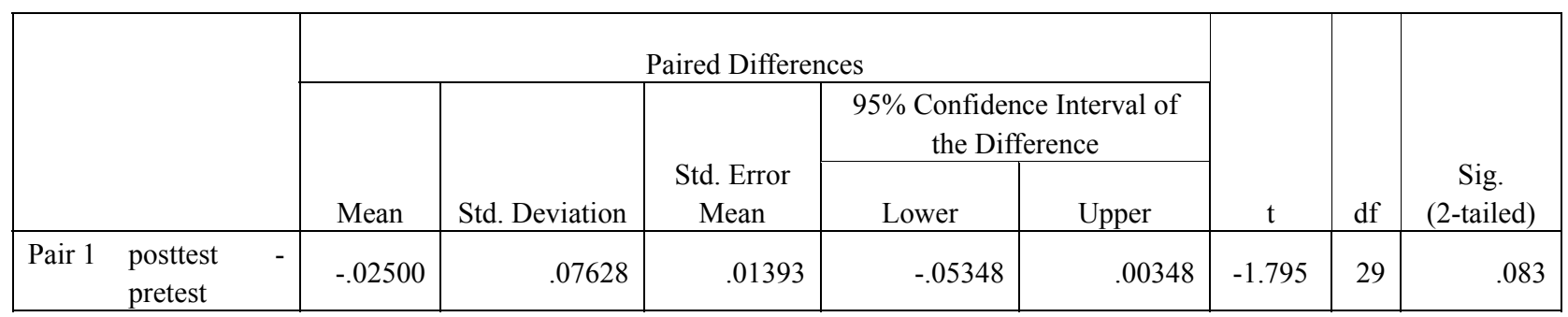


Table 3. Descriptive statistics of the experimental group in the pre-test and the post-test

\begin{tabular}{|cc|c|c|c|c|}
\hline & Mean & N & Std. Deviation & Std. Error Mean \\
\hline Pair 1 & pretest & 5.7500 & 30 & .31486 & .05749 \\
& posttest & 6.8000 & 30 & .40684 & .07428 \\
\hline
\end{tabular}

Table 4. Independent samples t-test for the pre-test and post-test differences in the experimental group

\begin{tabular}{|c|c|c|c|c|c|c|c|c|}
\hline & \multicolumn{5}{|c|}{ Paired Differences } & \multirow[b]{3}{*}{$\mathrm{t}$} & \multirow[b]{3}{*}{ df } & \multirow{3}{*}{$\begin{array}{c}\text { Sig. } \\
\text { (2-tailed) }\end{array}$} \\
\hline & \multirow[b]{2}{*}{ Mean } & \multirow{2}{*}{$\begin{array}{c}\text { Std. } \\
\text { Deviation }\end{array}$} & \multirow{2}{*}{$\begin{array}{l}\text { Std. Error } \\
\text { Mean }\end{array}$} & \multicolumn{2}{|c|}{$\begin{array}{c}95 \% \text { Confidence Interval of } \\
\text { the Difference }\end{array}$} & & & \\
\hline & & & & Lower & Upper & & & \\
\hline Pair 1 posttest - pretest & -1.05000 & .53094 & .09694 & -1.24826 & -.85174 & -10.832 & 29 & .000 \\
\hline
\end{tabular}

Table 5. Group statistics of gender differences in the experimental group

\begin{tabular}{|c|c|c|c|c|}
\hline Gender & $\mathrm{N}$ & Mean & Std. Deviation & Std. Error Mean \\
\hline $\begin{array}{c}\text { Post-test } \\
\text { Female } \\
\text { Male }\end{array}$ & 21 & 6.3333 & .24152 & .05270 \\
.11111 \\
\hline
\end{tabular}

Table 6. T-test for gender differences in the experimental group

\begin{tabular}{|c|c|c|c|c|c|c|c|c|c|c|}
\hline & \multicolumn{2}{|c|}{$\begin{array}{c}\text { Levene's Test for } \\
\text { Equality of } \\
\text { Variances }\end{array}$} & \multicolumn{7}{|c|}{ t-test for Equality of Means } \\
\hline & & \multirow[b]{2}{*}{$\mathrm{F}$} & \multirow[b]{2}{*}{ Sig. } & \multirow[b]{2}{*}{$\mathrm{t}$} & \multirow[b]{2}{*}{ df } & \multirow{2}{*}{$\begin{array}{c}\text { Sig. } \\
\text { (2-tailed) }\end{array}$} & \multirow{2}{*}{$\begin{array}{c}\text { Mean } \\
\text { Difference }\end{array}$} & \multirow{2}{*}{$\begin{array}{l}\text { Std. Error } \\
\text { Difference }\end{array}$} & \multicolumn{2}{|c|}{$\begin{array}{l}95 \% \text { Confidence } \\
\text { Interval of the } \\
\text { Difference }\end{array}$} \\
\hline & & & & & & & & & Lower & Upper \\
\hline Post-test & $\begin{array}{r}\text { Equal variances } \\
\text { assumed }\end{array}$ & .585 & .451 & -.515 & 28 & .611 & -.05556 & .10795 & -.27668 & .16557 \\
\hline & $\begin{array}{r}\text { Equal variances not } \\
\text { assumed }\end{array}$ & & & -.452 & 11.767 & .660 & -.05556 & .12298 & -.32409 & .21298 \\
\hline
\end{tabular}

Table 7. Means of all study variables

\begin{tabular}{|l|c|c|c|c|c|c|c|c|c|c|}
\hline \multicolumn{10}{|c|}{ Statistics } \\
\hline $\mathrm{N}$ & $\mathrm{q} 1$ & $\mathrm{q} 2$ & $\mathrm{q} 3$ & $\mathrm{q} 4$ & $\mathrm{q} 5$ & $\mathrm{q} 6$ & $\mathrm{q} 7$ & $\mathrm{q} 8$ & $\mathrm{q} 9$ & $\mathrm{q} 10$ \\
\hline & & & & & & & & & & \\
Mean & 1.9333 & 2.2667 & 1.6667 & 2.8667 & 2.4333 & 2.3667 & 2.7333 & 1.5333 & 1.8333 & 1.4333 \\
\hline
\end{tabular}


Table 8. Chi-Square Test 1: Differences in students' responses to the Questionnaire items

\begin{tabular}{|c|c|c|c|c|c|c|c|c|c|c|c|}
\hline & & $\mathrm{q} 1$ & $\mathrm{q} 2$ & $\mathrm{q} 3$ & $\mathrm{q} 4$ & q5 & q6 & $\mathrm{q} 7$ & q8 & q9 & $\mathrm{q} 10$ \\
\hline Chi-Square & & $9.800^{\mathrm{a}}$ & $3.200^{\mathrm{a}}$ & $5.000^{\mathrm{a}}$ & $9.200^{\mathrm{b}}$ & $26.600^{\mathrm{a}}$ & $25.400^{\mathrm{a}}$ & $18.800^{b}$ & $.133^{\mathrm{c}}$ & $13.333^{\mathrm{c}}$ & $.533^{\mathrm{c}}$ \\
\hline df & & 2 & 2 & 2 & 3 & 2 & 2 & 3 & 1 & 1 & 1 \\
\hline Asymp. Sig. & & .007 & .202 & .082. & .027 & .000 & .000 & .000 & .715 & .000 & .465 \\
\hline Monte Sig. & & $.008^{\mathrm{d}}$ & $.211^{\mathrm{d}}$ & $.090^{\mathrm{d}}$ & $.026^{\mathrm{d}}$ & $.000^{\mathrm{d}}$ & $.000^{\mathrm{d}}$ & $.000^{\mathrm{d}}$ & $.855^{\mathrm{d}}$ & $.000^{\mathrm{d}}$ & $.588^{\mathrm{d}}$ \\
\hline $\begin{array}{r}99 \% \text { Confidence } \\
\text { Interval }\end{array}$ & $\begin{array}{l}\text { Lower } \\
\text { Bound }\end{array}$ & .005 & 201 & .083 & .022 & .000 & |000. & .000 & .846 & .000 & .576 \\
\hline & $\begin{array}{r}\text { Upper } \\
\text { Bound }\end{array}$ & .010 & .222 & .097 & .030 & .000 & .000 & .001 & .864 & .000 & .601 \\
\hline
\end{tabular}

Table 9. Chi-Square Test 2: Gender differences in the Questionnaire data

\begin{tabular}{|l|c|c|c|c|c|c|c|c|c|c|}
\hline & $\mathrm{q} 1$ & $\mathrm{q} 2$ & $\mathrm{q} 3$ & $\mathrm{q} 4$ & $\mathrm{q} 5$ & $\mathrm{q} 6$ & $\mathrm{q} 7$ & $\mathrm{q} 8$ & $\mathrm{q} 9$ & $\mathrm{q} 10$ \\
\hline Chi-Square & $2.827^{\mathrm{a}}$ & $4.490^{\mathrm{a}}$ & $.794^{\mathrm{a}}$ & $6.043^{\mathrm{a}}$ & $.462^{\mathrm{a}}$ & $1.981^{\mathrm{a}}$ & $2.202^{\mathrm{a}}$ & $.026^{\mathrm{a}}$ & $2.571^{\mathrm{a}}$ & $.006^{\mathrm{a}}$ \\
df & 2 & 2 & 2 & 3 & 2 & 2 & 3 & 1 & 1 & 1 \\
Asymp. Sig. (2-sided) & .243 & .106 & .672 & .110 & .794 & .371 & .531 & .873 & .109 & .936 \\
Sig. & $.301^{\mathrm{b}}$ & $.124^{\mathrm{b}}$ & $.760^{\mathrm{b}}$ & $.111^{\mathrm{b}}$ & $1.000^{\mathrm{b}}$ & $.523^{\mathrm{b}}$ & $.668^{\mathrm{b}}$ & 1.000 & .286 & 1.000 \\
\hline
\end{tabular}

Table 10. Applicants' absolute IM frequencies

\begin{tabular}{|c|c|c|c|c|c|c|c|}
\hline \multirow{2}{*}{} & \multicolumn{3}{|c|}{ Verbal tactics (f) } & \multicolumn{3}{c|}{ Nonverbal tactics (f) } \\
\cline { 2 - 7 } & $\begin{array}{c}\text { Time-stalling } \\
\text { devices }\end{array}$ & Circumlocution & $\begin{array}{c}\text { Appeal for } \\
\text { assistance }\end{array}$ & $\begin{array}{c}\text { Hand } \\
\text { gesture }\end{array}$ & Eye contact & Smiling & $\begin{array}{c}\text { Head } \\
\text { nodding }\end{array}$ \\
\hline $\mathrm{N}$ & 340 & 183 & 75 & 158 & 299 & 86 & 65 \\
\hline
\end{tabular}

Table 11. Descriptive statistics of the Videotape data

\begin{tabular}{|l|c|c|c|c|c|}
\hline & $\mathrm{N}$ & Minimum & Maximum & Mean & Std. Deviation \\
\hline Time-stalling devices (v1) & 30 & .27 & 1.00 & .7556 & .22782 \\
\hline $\begin{array}{l}\text { Circumlocution } \\
\text { (v2) }\end{array}$ & 30 & .13 & .60 & .4067 & .13142 \\
\hline Appeal for assistance (v3) & 30 & .07 & .40 & .1667 & .10019 \\
\hline $\begin{array}{l}\text { Hand gesture } \\
\text { (n1) }\end{array}$ & 30 & .00 & .53 & .3511 & .19412 \\
\hline $\begin{array}{l}\text { Eye contact } \\
(\mathrm{n} 2)\end{array}$ & 30 & .27 & 1.00 & .6644 & .28148 \\
\hline $\begin{array}{l}\text { Smiling } \\
(\mathrm{n} 3)\end{array}$ & 30 & .00 & .60 & .1911 & .19553 \\
\hline $\begin{array}{l}\text { Head nodding } \\
\text { (n4) }\end{array}$ & 30 & .00 & .60 & .1444 & .17427 \\
\hline Valid N & 30 & & & & \\
\hline
\end{tabular}


Table 12. Group statistics of gender differences in the Videotape data

\begin{tabular}{|ll|c|c|c|c|}
\hline & Gender & $\mathrm{N}$ & Mean & Std. Deviation & Std. Error Mean \\
\hline v1 & Famale & 21 & .7524 & .23865 & .05208 \\
& Male & 9 & .7630 & .21373 & .07124 \\
\hline v2 & Famale & 21 & .3873 & .14394 & .03141 \\
& Male & 9 & .4519 & .08678 & .02893 \\
\hline v3 & Famale & 21 & .1873 & .11278 & .02461 \\
& Male & 9 & .1185 & .02940 & .00980 \\
\hline $\mathrm{n} 1$ & Famale & 21 & .3333 & .21396 & .04669 \\
& Male & 9 & .3926 & .13922 & .05903 \\
\hline $\mathrm{n} 2$ & Famale & 21 & .6349 & .27049 & .10364 \\
\hline $\mathrm{n} 3$ & Male & 9 & .7333 & .31091 & .04634 \\
& Famale & 21 & .2413 & .21237 & .02062 \\
\hline $\mathrm{n} 4$ & Male & 9 & .0741 & .06186 & .03735 \\
\end{tabular}

Table 13. T-test for gender differences in the Videotape data

\begin{tabular}{|c|c|c|c|c|c|c|c|c|c|}
\hline & \multicolumn{2}{|c|}{$\begin{array}{c}\text { Levene's Test for } \\
\text { Equality of Variances }\end{array}$} & \multicolumn{7}{|c|}{ T-test for Equality of Means } \\
\hline & \multirow[b]{2}{*}{$\mathrm{F}$} & \multirow[b]{2}{*}{ Sig. } & \multirow[b]{2}{*}{$\mathrm{t}$} & \multirow[b]{2}{*}{$\mathrm{df}$} & \multirow{2}{*}{$\underset{\text { (2-tailed) }}{\text { Sig. }}$} & \multirow{2}{*}{$\begin{array}{c}\text { Mean } \\
\text { Difference }\end{array}$} & \multirow{2}{*}{$\begin{array}{l}\text { Std. Error } \\
\text { Difference }\end{array}$} & \multicolumn{2}{|c|}{$\begin{array}{l}95 \% \text { Confidence Interval } \\
\text { of the Difference }\end{array}$} \\
\hline & & & & & & & & Lower & Upper \\
\hline $\begin{array}{l}\text { v1 Equal variances } \\
\text { assumed }\end{array}$ & .250 & .621 & -.115 & 28 & .910 & -.01058 & .09235 & -.19976 & .17859 \\
\hline $\begin{array}{l}\text { Equal variances } \\
\text { not assumed }\end{array}$ & & & -.120 & 16.903 & .906 & -.01058 & .08825 & -.19685 & .17568 \\
\hline $\begin{array}{l}\text { v2 Equal variances } \\
\text { assumed }\end{array}$ & .886 & .355 & -1.244 & 28 & .224 & -.06455 & .05187 & -.17081 & .04170 \\
\hline $\begin{array}{l}\text { Equal variances } \\
\text { not assumed }\end{array}$ & & & -1.512 & 24.412 & .143 & -.06455 & .04270 & -.15260 & .02350 \\
\hline $\begin{array}{l}\text { v3 Equal variances } \\
\text { assumed }\end{array}$ & 10.827 & .003 & 1.787 & 28 & .085 & .06878 & .03849 & -.01006 & .14762 \\
\hline $\begin{array}{l}\text { Equal variances } \\
\text { not assumed }\end{array}$ & & & 2.597 & 25.257 & .015 & .06878 & .02649 & .01425 & .12331 \\
\hline $\begin{array}{l}\text { n1 Equal variances } \\
\text { assumed }\end{array}$ & 3.739 & .063 & -.761 & 28 & .453 & -.05926 & .07791 & -.21884 & .10032 \\
\hline $\begin{array}{l}\text { Equal variances } \\
\text { not assumed }\end{array}$ & & & -.900 & 22.976 & .377 & -.05926 & .06583 & -.19545 & .07693 \\
\hline $\begin{array}{l}\text { n2 } \begin{array}{l}\text { Equal variances } \\
\text { assumed }\end{array} \\
\text { a }\end{array}$ & 1.074 & .309 & -.874 & 28 & .390 & -.09841 & .11260 & -.32907 & .13224 \\
\hline $\begin{array}{l}\text { Equal variances } \\
\text { not assumed }\end{array}$ & & & -.825 & 13.465 & .424 & -.09841 & .11927 & -.35517 & .15835 \\
\hline $\begin{array}{l}\text { n3 Equal variances } \\
\text { assumed }\end{array}$ & 28.130 & .000 & 2.299 & 28 & .029 & .16720 & .07271 & .01825 & .31614 \\
\hline $\begin{array}{l}\text { Equal variances } \\
\text { not assumed }\end{array}$ & & & 3.296 & 26.142 & .003 & .16720 & .05072 & .06296 & .27143 \\
\hline $\begin{array}{l}\text { n4 Equal variances } \\
\text { assumed }\end{array}$ & .022 & .883 & .225 & 28 & .824 & .01587 & .07060 & -.12874 & .16048 \\
\hline $\begin{array}{l}\text { Equal variances } \\
\text { not assumed }\end{array}$ & & & .215 & 13.770 & .833 & .01587 & .07395 & -.14299 & .17473 \\
\hline
\end{tabular}


Table 14. Correlation between verbal and nonverbal IM tactics

\begin{tabular}{|c|c|c|c|c|c|c|c|c|}
\hline & & $\mathrm{v} 1$ & v2 & v3 & $\mathrm{n} 1$ & $\mathrm{n} 2$ & n3 & $\mathrm{n} 4$ \\
\hline \multirow[t]{2}{*}{$\mathrm{v} 1$} & Pearson Correlation & 1 & $.461^{*}$ & $-.564^{* *}$ & .025 & .056 & -.054 & -.300 \\
\hline & Sig. (2-tailed) & & .010 & .001 & .894 & .770 & .777 & .107 \\
\hline \multirow[t]{2}{*}{ v2 } & Pearson Correlation & & 1 & $-.693^{* *}$ & $.560^{* *}$ & .162 & -.075 & $-.478^{* *}$ \\
\hline & Sig. (2-tailed) & & & .000 & .001 & .392 & .693 & .007 \\
\hline \multirow[t]{2}{*}{ v3 } & Pearson Correlation & & & 1 & -.315 & .133 & .289 & $.496^{* *}$ \\
\hline & Sig. (2-tailed) & & & & .090 & .483 & .121 & .005 \\
\hline \multirow[t]{2}{*}{ n1 } & Pearson Correlation & & & & 1 & .197 & .134 & -.273 \\
\hline & Sig. (2-tailed) & & & & & .297 & .482 & .144 \\
\hline \multirow[t]{2}{*}{ n2 } & Pearson Correlation & & & & & 1 & .156 & $.416^{*}$ \\
\hline & Sig. (2-tailed) & & & & & & .412 & .022 \\
\hline \multirow[t]{2}{*}{ n3 } & Pearson Correlation & & & & & & 1 & .057 \\
\hline & Sig. (2-tailed) & & & & & & & .765 \\
\hline \multirow[t]{2}{*}{ n4 } & Pearson Correlation & & & & & & & 1 \\
\hline & Sig. (2-tailed) & & & & & & & \\
\hline
\end{tabular}

Table 15. Correlation between applicants' IM tactics and the post-test scores

\begin{tabular}{|c|c|c|c|c|c|c|c|c|}
\hline & & $\mathrm{mv1}$ & $\mathrm{mv} 2$ & $\mathrm{mv} 3$ & $\mathrm{mn} 1$ & $\mathrm{mn} 2$ & $\mathrm{mn} 3$ & $\mathrm{mn} 4$ \\
\hline \multirow{2}{*}{ Post Exp } & Pearson Correlation & $.583^{* *}$ & $.649^{* *}$ & $-.423^{*}$ & $.425^{*}$ & .046 & $.439^{*}$ & $-.600^{* *}$ \\
\cline { 2 - 10 } & Sig. (2-tailed) & .001 & .000 & .020 & .019 & .809 & .015 & .000 \\
\hline
\end{tabular}

